\title{
ESTIMASI POTENSI GENETIK SAPI PERAH FRIESIAN HOLSTEIN DI TAURUS DAIRY FARM, CICURUG, SUKABUMI
}

\section{GENETIC POTENTIAL ESTIMATION OF FRIESIAN HOLSTEIN COWS AT TAURUS DAIRY FARM, CICURUG, SUKABUMI}

\author{
Hera Prahanisa*, Sumadi, dan Adiarto \\ Fakultas Peternakan, Universitas Gadjah Mada, Jl Fauna No. 3, Bulaksumur, Yogyakarta, 55281
}

\section{INTISARI}

Penelitian ini bertujuan untuk menduga potensi genetik sapi perah Friesian Holstein di Taurus Dairy Farm Cicurug, Sukabumi. Data yang diambil adalah data sekunder berupa catatan produksi susu, jarak beranak (calving interval) (CI), service per conception (S/C), umur beranak pertama, dan lama laktasi sapi perah yang telah mengalami $\geq 1$ kali laktasi sejak tahun 2003 sampai 2009, kemudian dilakukan standarisasi terhadap produksi susu dengan menggunakan faktor koreksi lama pemerahan 305 hari, dan umur induk dewasa. Data sifat (produksi susu), sifat reproduksi (CI, S/C, lama laktasi, dan umur beranak pertama) dianalisis secara statistik deskriptif. Data dianalisis dengan menggunakan analisis variansi korelasi saudara tiri sebapak (paternal halfsib correlation) dan pola tersarang (nested) untuk mendapatkan nilai heritabilitas, sedangkan nilai ripitabilitas diperoleh dengan menggunakan metode korelasi antar kelas dan korelasi intra kelas. Nilai heritabilitas dan ripitabilitas digunakan untuk menghitung nilai most probable producing ability (MPPA), estimated real producing ability (ERPA), estimated transmitting ability (ETA), dan breeding value (NP) sapi perah. Estimasi nilai heritabilitas produksi susu dengan metode pola tersarang sebesar $0,287 \pm 0,135\left(\mathrm{~h}_{\mathrm{s}}^{2}\right), 0,310 \pm 0,154\left(\mathrm{~h}_{\mathrm{d}}^{2}\right)$, dan $0,299 \pm 0,103\left(\mathrm{~h}_{(\mathrm{d}+\mathrm{s})}^{2}\right)$, dan metode korelasi saudara tiri sebapak 0,63 $\pm 0,23$. Estimasi nilai heritabilitas CI dengan metode saudara tiri $0,46 \pm 0,23$, dan pola tersarang $0,038 \pm 0,106\left(\mathrm{~h}_{\mathrm{s}}{ }_{\mathrm{s}}\right), 0,733 \pm 0,231$ $\left(\mathrm{h}_{\mathrm{d}}^{2}\right), 0,385 \pm 0,117\left(\mathrm{~h}^{2}(\mathrm{~d}+\mathrm{s})\right.$. Estimasi heritabilitas $\mathrm{S} / \mathrm{C}$ dengan metode saudara tiri $0,001 \pm 0,110$ dan dengan pola tersarang $-0,022 \pm 0,043\left(\mathrm{~h}_{\mathrm{s}}^{2}\right), 0,098 \pm 0,133\left(\mathrm{~h}_{\mathrm{d}}^{2}\right), 0,038 \pm 0,072\left(\mathrm{~h}_{(\mathrm{d}+\mathrm{s})}^{2}\right)$. Estimasi nilai ripitabilitas produksi susu korelasi antar kelas $0,43 \pm 0,1$ dan korelasi intra kelas $0,15 \pm 0,05$. Nilai ripitabilitas CI dengan metode korelasi antar kelas $0,00 \pm 0,09$ dan korelasi intra kelas $0,19 \pm 0,07$. Nilai ripitabilitas $\mathrm{S} / \mathrm{C}$ dengan metode korelasi antar kelas $0,12 \pm 0,15$ dan korelasi intra kelas $0,02 \pm 0,05$. Hasil perhitungan diperoleh peringkat lima tertinggi berdasarkan estimasi nilai relatif MPPA dan ERPA 147 ekor induk dengan metode ripitabilitas antar kelas dan 279 ekor induk dengan metode ripitabilitas intra kelas adalah sapi perah dengan nomor 1966, 1941, 2180, 2087, dan 2248. Database, Kimball, Beam, Doeboy, Paul, Varlour, dan Cassela memperoleh peringkat tertinggi untuk estimasi nilai ETA dan NP dari 40 ekor pejantan dengan metode heritabilitas saudara tiri sebapak dan 38 ekor pejantan dengan metode heritabilitas pola tersarang.

(Kata kunci: Sapi perah Friesian Holstein, Produksi susu, Sifat reproduksi, Parameter genetik)

\section{ABSTRACT}

The objective of this study was to estimate potential genetic of Friesian Holstein at Taurus Dairy Farm, Cicurug, Sukabumi. Data observed were secondary data of milk yield, calving interval, service per conception, age at first calving, and length of lactation records of cows that have been experiencing one or more lactation since year 2003 to 2009, then were standardized based on milk yield by using correction factor 305 days of lactation period and mature equivalent (ME). Production trait (milk yield), reproduction traits (CI, S/C, length of lactation, and age at first calving) were analyzed by descriptive statistic. Data were analyzed by paternal half-sib correlation and nested method to get heritability, while the repeatability value were obtained by interclass and intraclass correlation method. Heritability and repeatability value then was used to count most probable producing ability (MPPA) and estimated real producing ability value and estimated transmitting ability (ETA) and breeding value (NP) of dairy cows. Estimates of heritability of milk yield by using nested are $0.287 \pm 0.135\left(h_{s}{ }_{s}\right), 0.310 \pm 0.154\left(h^{2}{ }_{d}\right)$, and $0.299 \pm 0.103\left(h^{2}{ }_{(d+s)}\right)$, and paternal half-sib correlation method was $0.63 \pm 0.23$. Estimates of CI heritability with paternal half-sib method was $0.46 \pm 0.23$, and values obtained using nested were 0.038 $\pm 0.106\left(h_{s}^{2}\right), 0.733 \pm 0.231\left(h^{2}{ }_{d}\right), 0.385 \pm 0.117\left(h^{2}{ }_{(d+s)}\right)$. Estimated heritability of S/C with paternal half-sib method was $0.001 \pm 0.110$ and using nested method are $-0.022 \pm 0.043\left(h_{s}^{2}\right), 0.098 \pm 0.133\left(h^{2}{ }_{d}\right)$, $0.038 \pm 0.072\left(h^{2}(d+s)\right)$. Estimated value of milk yield repeatability with interclass correlation was $0.43 \pm 0.1$ and intraclass correlation was $0.15 \pm 0.05$. CI repeatability value with interclass correlation method was $0.00 \pm 0.09$ and intraclass

\footnotetext{
$\bar{*}$ Korespondensi (corresponding author):

Telp. +62 8195196 756, E-mail: shiver-her@yahoo.com
} 
correlation was $0.19 \pm 0.07$. S/C repeatability value with interclass correlation method was $0.12 \pm 0.15$ and intraclass correlation was $0.02 \pm 0.05$. Based on the calculation, the highest five ranks on the estimated relative value of MPPA and ERPA from 147 holstein friesian dairy cows with interclass repeatability method and 279 Friesian Holstein dairycows with intraclass method were 1966, 1941, 2180, 2087, and 2248. Database, Kimball, Beam, Doeboy, Paul, Varlour and Cassela get the highest rank, based on the estimated value of ETA and NP for 40 bulls using paternal halfsib heritability method and 38 bulls using nested heritability method.

(Keywords: Friesian Holstein dairy cows, Milk yield, Reproduction traits, Genetic parameter)

\section{Pendahuluan}

Produksi dan produktivitas sapi perah Friesian Holstein ditentukan oleh dua faktor utama, yaitu faktor genetik dan faktor lingkungan, meskipun terkadang juga ditentukan oleh faktor lain yaitu interaksi antara faktor genetik dan lingkungan yang tidak berpengaruh secara bebas atau sendirisendiri (Hardjosubroto, 1994). Faktor genetik ini dapat diwariskan kepada keturunannya. Estimasi potensi genetik diperlukan untuk mengetahui seberapa besar sifat-sifat yang dapat diwariskan tetua kepada keturunannya sehingga dapat diketahui ternak mana yang mempunyai sifat produksi dan reproduksi tinggi untuk diseleksi (Lasley, 1978). Potensi genetik tersebut antara lain heritabilitas dan ripitabilitas. Ketika heritabilitas suatu sifat tinggi, maka seleksi fenotipik akan lebih efektif untuk dilakukan (Pollack, 1998). Heritabilitas yang lebih tinggi pada suatu sifat, lebih besar pula kemajuan genetik yang dapat dibuat (Foley et al., 1973). Pendugaan ripitabilitas suatu sifat berguna dalam meramalkan produksi seekor ternak yang telah mempunyai satu atau lebih catatan produksi (Warwick et al., 1990). Nilai ripitabilitas biasanya dihitung dengan menggunakan korelasi intra kelas dan korelasi dalam kelas oleh ternak yang sama pada laktasi yang berbeda (Falconer dan Mackay, 1996). Estimasi ripitabilitas digunakan untuk menyingkirkan ternak secara aman dengan berdasarkan catatan yang telah ada (Mustafa et al., 2002).

Taurus Dairy Farm merupakan salah satu peternakan sapi perah di Indonesia yang berskala cukup besar. Data pada bulan Desember 2009 menunjukkan Taurus Dairy Farm memiliki total sapi sebanyak 689 ekor sapi perah Friesian Holstein yang berproduksi tinggi dan telah mengalami laktasi beberapa kali, yang terdiri atas 385 ekor sapi induk dan 304 ekor sapi replacement dengan rerata produksi susu sapi per hari 4.112 sampai 4.420,4 $\mathrm{kg}$. Menurut Soetarno (2000), produksi susu sapi Friesian Holstein selama laktasi 5.707,8 kg. Dengan memiliki catatan yang akurat mengenai produksi susu, calving interval (CI), service per conception (S/C), dan umur beranak pertama, diharapkan dapat digunakan untuk mengestimasi potensi genetik yang dimiliki oleh sapi perah yang dipelihara di Taurus
Dairy Farm. Oleh karena itu, penelitian ini dilakukan untuk menduga potensi genetik sapi perah Friesian Holstein di Taurus Dairy Farm Cicurug, Sukabumi, dilihat dari segi kemampuan mewariskan genetiknya, sehingga dapat digunakan untuk pengembangan pengetahuan, juga dapat dijadikan sebagai dasar seleksi sapi perah betina yang dipelihara, sebagai informasi untuk perbaikan tata laksana produksi, serta dapat dimanfaatkan dalam penyusunan rencana pemuliaan sapi perah secara praktis guna meningkatkan produksi susu.

\section{Materi dan Metode}

\section{Materi}

Penelitian ini dilaksanakan sejak tanggal 1 Juli sampai 7 Agustus 2010. Tempat pelaksanaan penelitian di Taurus Dairy Farm, Cicurug, Sukabumi. Materi yang digunakan dalam penelitian ini adalah catatan produksi susu, calving interval (CI), service per conception $(\mathrm{S} / \mathrm{C})$, dan umur beranak pertama sapi perah $\mathrm{FH}$ yang dipelihara di Taurus Dairy Farm, Cicurug, Sukabumi. Data diambil berdasarkan sapi perah keturunan pejantan BIB Lembang, Kanada, Australia, Amerika (USA), dan pejantan Taurus Dairy Farm yang telah mengalami $\geq 1$ kali laktasi sejak tahun 2003 hingga 2009. Penghitungan produksi susu laktasi pertama, kedua, ketiga, dan keempat secara berturut-turut menggunakan catatan sebanyak 290, 143, 94, dan 63 ekor. Penghitungan reproduksi sifat CI, umur beranak pertama, S/C, dan lama laktasi secara berturut-turut menggunakan catatan 287, 396, 393, dan 286 ekor.

\section{Metode}

Data yang diambil berupa data sekunder pada produksi susu, $\mathrm{CI}, \mathrm{S} / \mathrm{C}$, dan umur beranak pertama sejak tahun 2003 sampai 2009, kemudian dilakukan standarisasi terhadap produksi susu dengan menggunakan faktor koreksi lama pemerahan 305 hari, umur induk dewasa, dan pemerahan 2 kali/hari (Hardjosubroto, 1994).

Penghitungan produksi susu dan sifat reproduksi (CI dan S/C) menggunakan microsoft excel dan SAS 9.1 (Statistical Analysis System). Penghitungan nilai heritabilitas dengan menggunakan data saudara tiri sebapak (paternal 
halfsib correlation), dengan model statistik: $\mathrm{n}$ $Y_{i k}=\mu+\alpha_{i}+e_{i k}$

Penghitungan nilai heritabilitas menggunakan analisis sidik ragam pola tersarang (nested) (Hardjosubroto, 1994), dengan model statistik: $Y_{i j k}=\mu+\alpha_{i}+\beta_{i j}+e_{i j k}$

Pendugaan nilai ripitabilitas dengan korelasi antar kelas (interclass correlation). Metode ini dilakukan pada kelompok ternak yang memiliki 2 catatan produksi (Becker, 1992).

Penghitungan nilai ripitabilitas dengan korelasi dalam kelas (intraclass correlation). Analisis yang digunakan adalah rancangan acak lengkap pola searah. Metode ini dilakukan pada kelompok ternak yang memiliki lebih dari 2 catatan produksi (Becker, 1992).

Most probable producing ability (MPPA) dan estimated real producing ability (ERPA) produksi susu induk dihitung dengan menggunakan rumus sebagai berikut (Hardjosubroto, 1994):

$$
\begin{aligned}
& \text { MPPA absolut }=\frac{n r}{1+(n-1) r}(\bar{P}-\overline{\bar{P}})+\overline{\bar{P}} \\
& \text { MPPA relatif }=\frac{n r}{1+(n-1) r}(\bar{P}-\overline{\bar{P}}) \\
& \text { ERPA absolut }=\frac{n r}{1+(n-1) r}\left(\bar{P}-\overline{\overline{P_{H}}}\right)+\overline{\overline{P_{H}}} \\
& \text { ERPA relatif }=
\end{aligned}
$$

\section{Keterangan:}

MPPA, ERPA = penduga kemampuan berproduksi

$\mathrm{r}=$ ripitabilitas produksi susu

$\mathrm{n}=$ jumlah pengamatan

$\bar{P} \quad=$ rerata produksi susu yang diduga

$\overline{\bar{P}} \quad=$ rerata produksi susu populasi

$\overline{\bar{P}}_{H}=$ rerata produksi herdmate

Perbandingan antar produksi anak merupakan salah satu metode seleksi pejantan, yaitu cara seleksi dengan membandingkan produksi anak betina dari pejantan satu dengan pejantan lainnya. Metode ini dikenal sebagai daughter comparison atau ETA.

$\mathrm{ETA}=(\mathrm{A})($ rerata produksi anak betina - rerata produksi populasinya)

Keterangan:

ETA = estimated transmitting ability

A = suatu konstanta yang besarnya diduga

$$
\text { dengan rumus: } \mathrm{A}=\frac{n}{n+\frac{\left(4-h^{2}\right)}{h^{2}}}
$$

$\mathrm{n} \quad=$ jumlah anak betina dari pejantan yang diuji

$\mathrm{h}^{2} \quad=$ nilai pewarisan (Hardjosubroto, 1994).

Nilai pemuliaan (NP) untuk pejantan (semen beku) dihitung dengan menggunakan rumus sebagai berikut (Hardjosubroto, 1994):

$$
\mathrm{NP}=\frac{n h^{2}}{1+(n-1) h^{2}}(\bar{P}-\overline{\bar{P}})
$$

\section{Keterangan:}

$\mathrm{NP}=$ nilai pemuliaan pejantan

$\mathrm{h}^{2}=$ heritabilitas produksi susu

$\mathrm{n}=$ jumlah pengamatan

$\bar{P} \quad=$ rerata produksi susu yang diduga dari pejantan yang diuji

$\bar{P} \quad=$ rerata produksi susu populasi

\section{Hasil dan Pembahasan}

\section{Most probable producing ability dan estimated real producing ability untuk seleksi induk}

Berdasarkan pendugaan daya produksi sapi betina diperoleh dengan dua metode, yaitu MPPA dan ERPA. Pada Tabel 1 perhitungan nilai MPPA dengan menggunakan ripitabilitas korelasi inter kelas dan intra kelas. Sapi perah yang mempunyai nilai MPPA tertinggi berdasarkan dua catatan produksi adalah sapi dengan nomor 2180, 2087, dan 2248, sebesar 4181,47; 4173,30; dan 4109,25 liter. Sapi perah yang mempunyai nilai MPPA tertinggi jika dihitung berdasarkan lebih dari dua catatan produksi adalah sapi dengan nomor 1966, 1941, dan 2180, sebesar 4853,23; 4487,27 dan 4368,44 liter (Tabel 1).

Hasil perhitungan ERPA dengan menggunakan ripitabilitas antar kelas diperoleh induk-induk yang memiliki produksi tertinggi yaitu 2180, 2087, dan 2248, sebesar 4181,47; 4173,30; dan 4109,25 liter (Tabel 2). Perhitungan ERPA menggunakan ripitabilitas intra kelas diperoleh induk-induk yang memiliki produksi tertinggi yaitu sapi nomor 1966, 1941, dan 2180, sebesar 4853,23; 4487,27 dan 4368,44 liter (Tabel 3).

Perbedaan nilai MPPA dan ERPA disebabkan nilai ripitabilitas yang berbeda. Ukuran error, atau secara umum, kondisi lingkungan yang bervariasi cenderung meningkatkan variasi temporer dan mengurangi nilai ripitabilitas (Dalton, 1980; Pirchner, 1968). Lasley (1978) menyatakan bahwa perkiraan nilai MPPA dan ERPA setiap ternak memiliki nilai ripitabilitas yang tinggi dan jumlah catatan yang lebih banyak akan meningkatkan ketepatan seleksi. Sapi-sapi perah yang mempunyai 
Tabel 1. Peringkat nilai MPPA sapi perah di Taurus Dairy Farm (the rank of MPPA value of dairy cows in Taurus Dairy Farm)

\begin{tabular}{|c|c|c|c|c|c|c|c|}
\hline \multirow{2}{*}{ No. } & \multicolumn{3}{|c|}{$\begin{array}{l}\text { Metode ripitabilitas inter kelas } \\
\text { (interclass repeatability method) }\end{array}$} & \multirow{2}{*}{ No. } & \multicolumn{3}{|c|}{$\begin{array}{l}\text { Metode ripitabilitas intra kelas } \\
\text { (intraclass repeatability method) }\end{array}$} \\
\hline & $\begin{array}{c}\text { No. sapi } \\
\text { (cow number) }\end{array}$ & MPPA & MPPA relative & & $\begin{array}{c}\text { No. sapi } \\
\text { (cow number) }\end{array}$ & MPPA & $\begin{array}{l}\text { MPPA } \\
\text { relative }\end{array}$ \\
\hline 1 & 2180 & 4181.47 & 261.69 & 1 & 1966 & 4853.23 & 933.44 \\
\hline 2 & 2087 & 4173.30 & 253.51 & 2 & 1941 & 4487.27 & 567.48 \\
\hline 3 & 2248 & 4109.25 & 189.46 & 3 & 2087 & 4368.44 & 448.66 \\
\hline 4 & 1941 & 4108.24 & 188.45 & 4 & 1763 & 4367.21 & 447.42 \\
\hline 5 & 2433 & 4102.20 & 182.42 & 5 & 2180 & 4355.74 & 435.95 \\
\hline . & . & 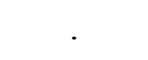 & . & 6 & 2584 & 4347.55 & 427.76 \\
\hline$\dot{145}$ & 1895 & 3673.24 & $-24 \dot{6.55}$ & . & & & . \\
\hline 146 & 1828 & 3669.92 & -249.87 & 277 & 1883 & 3319.66 & -600.13 \\
\hline 147 & 2593 & 3625.13 & -294.66 & 278 & 1795 & 3244.69 & -675.10 \\
\hline
\end{tabular}

nilai MPPA dan ERPA tertinggi di Taurus Dairy Farm adalah sapi dengan nomor 1966, 1941, 2180, 2087, dan 2248.

\section{Estimated transmitting ability dan nilai pemuliaan untuk seleksi pejantan}

Hasil perhitungan estimated transmitting ability (ETA) sapi jantan di Taurus Dairy Farm tercantum pada Tabel 4. Sapi perah jantan yang mempunyai ETA tertinggi dengan menggunakan metode heritabilitas saudara tiri adalah pejantan Paul, Database, dan Beam. Perhitungan nilai ETA dengan menggunakan metode heritabilitas pola tersarang terdapat pada Tabel 4. Sapi jantan yang mempunyai ETA tertinggi adalah Kimball, Cassela, dan Paul.

Hasil analisis nilai pemuliaan (NP) sapi jantan di Taurus Dairy Farm tercantum pada Tabel 5. Sapi perah jantan yang mempunyai NP tertinggi dengan menggunakan metode heritabilitas saudara tiri adalah pejantan Database, Doeboy, dan Paul.

Perbedaan nilai ETA dan NP hasil perhitungan disebabkan nilai heritabilitas yang digunakan juga berbeda. Falconer dan Mackay (1996) menyatakan bahwa hasil pendugaan nilai heritabilitas dapat berbeda-beda tergantung dari tempat, waktu penghitungan, metode, serta jumlah data yang digunakan. Apabila dihitung dengan menggunakan metode heritabilitas pola tersarang pejantan dengan NP tertinggi adalah Paul, Doeboy, dan Varlour. Berdasarkan hasil tersebut, pejantan yang dapat dianjurkan untuk mengawini betina kembali adalah Database, Kimball, Beam, Doeboy, Cassela, Paul, dan Varlour, tetapi jangan sampai terjadi inbreeding.

\section{Kesimpulan dan Saran}

\section{Kesimpulan}

Berdasarkan hasil analisis tentang parameter genetik sifat produksi dan reproduksi sapi perah yang dipelihara di Taurus Dairy Farm Cicurug, Sukabumi, maka dapat ditarik kesimpulan bahwa sapi-sapi yang memiliki nilai MPPA dan ERPA tertinggi di Taurus Dairy Farm adalah sapi-sapi keturunan USA dengan nomor 1966, 1941, 2180 , 2087, dan 2248. Pejantan yang mempunyai nilai ETA dan NP tertinggi adalah pejantan keturunan USA yaitu Database, Kimball, Beam, Doeboy, dan sapi-sapi keturunan BIB yaitu Paul, Varlour, dan Cassela.

\section{Saran}

Sapi perah betina yang mempunyai nilai MPPA relatif yang positif dapat dianjurkan untuk dipelihara, guna meningkatkan produksi susu di masa mendatang. Demikian pula dengan pejantan yang mempunyai ETA tertinggi dapat digunakan untuk mengawini betina lagi. Nilai MPPA dan ETA yang negatif sebaiknya diganti atau disingkirkan untuk tidak dikembangbiakkan lebih lanjut. Seleksi sapi-sapi dara yang akan dijadikan replacement harus memenuhi kriteria yang baik. Hal ini dapat dilihat melalui recording produksi dan reproduksi. Recording tersebut berguna untuk mengetahui silsilah agar terhindar dari inbreeding. Perbaikan manajemen recording dapat dilakukan dengan pencatatan secara computerize untuk mempermudah dalam pemeliharaan ternak. 


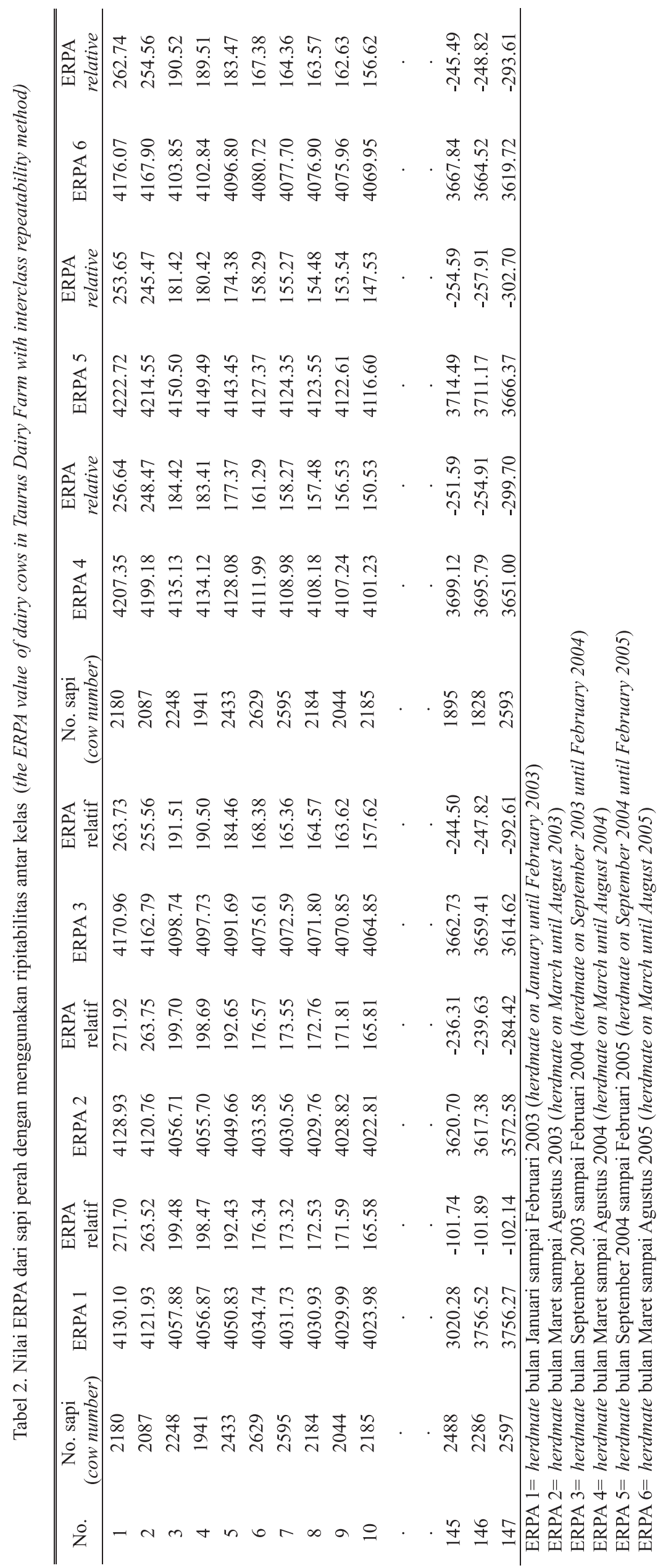




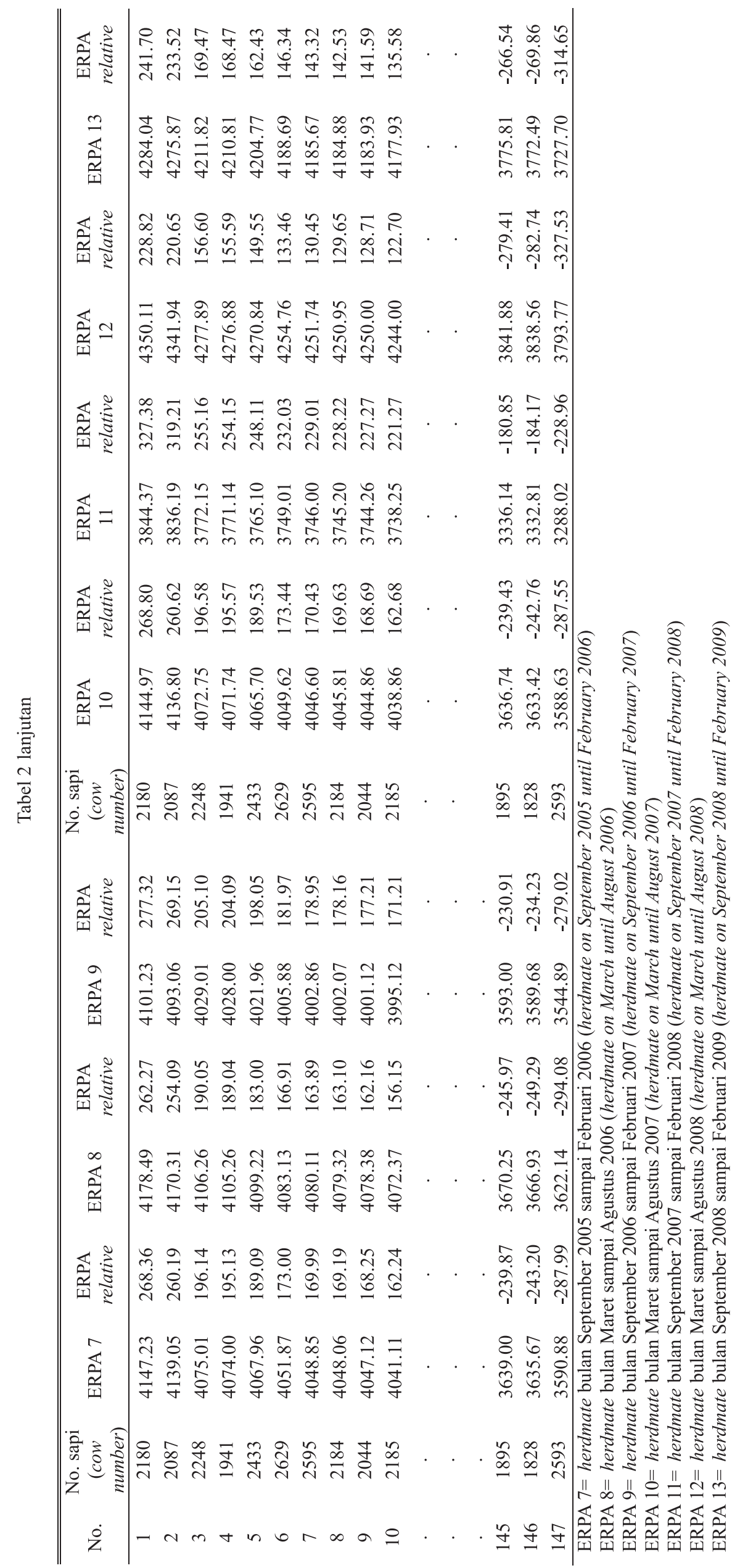




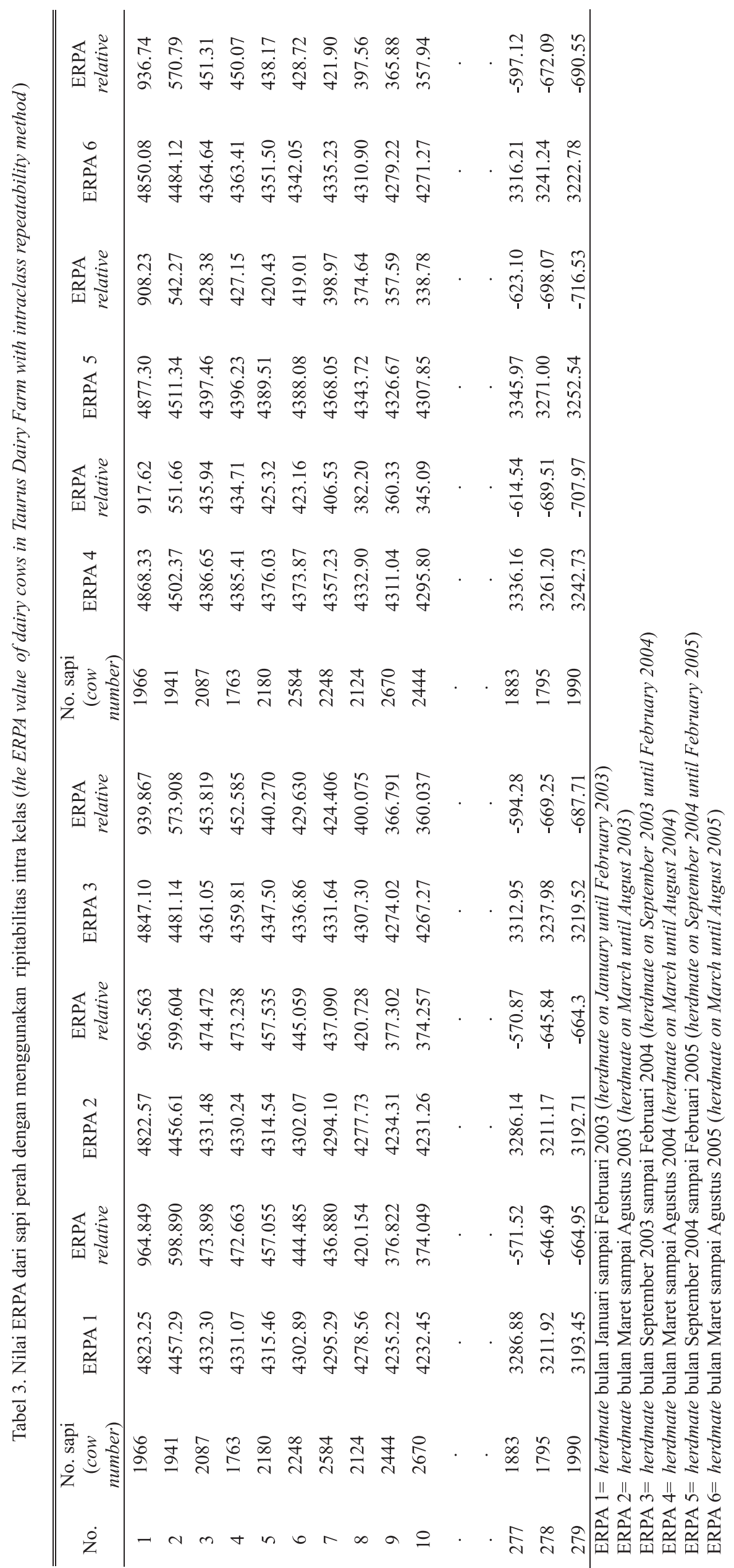




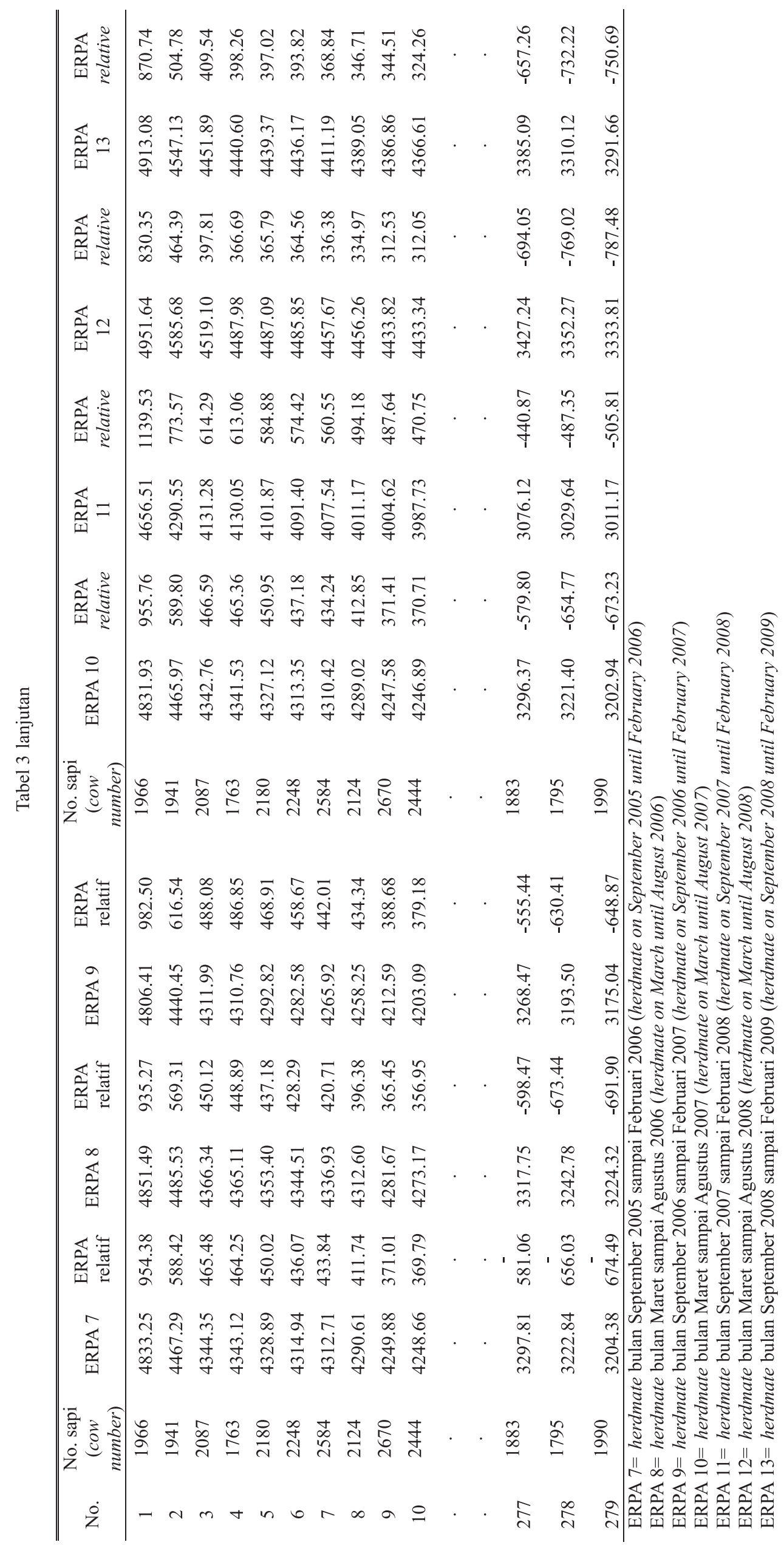


Tabel 4. Peringkat nilai ETA sapi perah di Taurus Dairy Farm (the rank of ETA value of dairy cows in Taurus Dairy Farm)

\begin{tabular}{|c|c|c|c|c|c|}
\hline \multirow[t]{2}{*}{ No. } & \multicolumn{2}{|c|}{$\begin{array}{c}\text { Dengan heritabilitas saudara tiri sebapak } \\
\text { (with paternal halfsib heritability) }\end{array}$} & \multirow[t]{2}{*}{ No. } & \multicolumn{2}{|c|}{$\begin{array}{l}\text { Dengan heritabilitas pola tersarang } \\
\text { (with nested heritability) }\end{array}$} \\
\hline & Nama pejantan (bull's name) & ETA & & Nama pejantan (bull's name) & ETA \\
\hline 1 & Paul & 762.92 & 1 & Kimball & 348.43 \\
\hline 2 & Database & 556.56 & 2 & Cassela & 209.14 \\
\hline 3 & Beam & 412.14 & 3 & Paul & 170.65 \\
\hline 4 & Monopoly & 397.55 & 4 & Marlow & 83.87 \\
\hline 5 & Marlow & 374.56 & 5 & Monopoly & 79.64 \\
\hline 6 & M.lazer & 368.48 & 6 & Justy & 78.12 \\
\hline 7 & Justy & 322.35 & 7 & Topwine & 65.24 \\
\hline 8 & Markwell & 311.65 & 8 & Doeboy & 57.40 \\
\hline 9 & Cassela & 248.39 & 9 & Varlour & 29.96 \\
\hline 10 & Doeboy & 233.14 & 10 & Rice & 26.59 \\
\hline$\cdot$ & $\cdot$ & $\cdot$ & . & $\cdot$ & $\cdot$ \\
\hline 38 & Baron & -435.40 & 36 & Karvilla jr & -187.18 \\
\hline 39 & Karvilla jr & -639.82 & 37 & Bromo & -266.37 \\
\hline 40 & Shoden & -830.69 & 38 & Baron & -312.76 \\
\hline
\end{tabular}

Tabel 5. Peringkat NP pejantan di Taurus Dairy Farm (the rank of NP of bull in Taurus Dairy Farm)

\begin{tabular}{|c|c|c|c|c|c|c|c|}
\hline \multirow{2}{*}{ No. } & \multicolumn{3}{|c|}{$\begin{array}{l}\text { Dengan heritabilitas saudara tiri sebapak } \\
\text { (with paternal halfsib heritability) }\end{array}$} & \multirow{2}{*}{ No. } & \multicolumn{3}{|c|}{$\begin{array}{l}\text { Dengan heritabilitas pola tersarang } \\
\text { (with nested heritability) }\end{array}$} \\
\hline & $\begin{array}{l}\text { Nama pejantan } \\
\text { (bull's name) }\end{array}$ & NP & NP relative & & $\begin{array}{l}\text { Nama pejantan } \\
\text { (bull's name) }\end{array}$ & NP & NP relative \\
\hline 1 & Database & 5208.03 & 1288.24 & 1 & Paul & 4555.99 & 636.20 \\
\hline 2 & Doeboy & 4852.33 & 932.54 & 2 & Doeboy & 4473.79 & 554.00 \\
\hline 3 & Paul & 4721.33 & 801.54 & 3 & Varlour & 4463.23 & 543.45 \\
\hline 4 & Beam & 4526.44 & 606.65 & 4 & Kimball & 4310.96 & 391.17 \\
\hline 5 & Monopoly & 4504.97 & 585.18 & 5 & Monopoly & 4269.29 & 349.51 \\
\hline 6 & Marlow & 4471.13 & 551.35 & 6 & Cassela & 4136.48 & 216.69 \\
\hline 7 & Justy & 4394.28 & 474.49 & 7 & Markwell & 4115.18 & 195.40 \\
\hline 8 & M. Lazer & 4358.68 & 438.89 & 8 & Marlow & 4062.44 & 142.65 \\
\hline 9 & M. Vista & 4282.35 & 362.56 & 9 & Justy & 3989.55 & 69.76 \\
\hline 10 & Kimball & 4255.93 & 336.14 & 10 & Rice & 3965.47 & 45.68 \\
\hline 38 & Varlour & 3325.25 & -594.54 & 36 & Baron & 3466.28 & -453.51 \\
\hline 39 & Jetstar & 3300.27 & -619.51 & 37 & Nilas & 3343.26 & -576.53 \\
\hline 40 & Shoden & 3269.77 & -650.02 & 38 & Karvilla Jr & 3208.87 & -710.92 \\
\hline
\end{tabular}

\section{Daftar Pustaka}

Becker, W.A. 1992. Manual of Quantitative Genetiks. $5^{\text {th }}$ ed. Academia Enterprises, Pullman, USA.

Dalton, D.C. 1980. An Introduction to Practical Animal Breeding. $2^{\text {nd }}$ ed. English Language Book Society. Cornell University, Ithaca, New York, USA.

Falconer, D.S. and T.F.C. Mackay. 1996. Introduction to Quantitative Genetics. $4^{\text {th }}$ ed. Longman, Inc, London, New York.
Foley, C., L. Bath, N. Dickinson, and H. Tucker. 1973. Dairy Cattle: Principles, Practices, Problems, Profits. Lea \& Febiger, Philadelphia.

Hardjosubroto, W. 1994. Aplikasi Pemuliaan Ternak di Lapangan. Grasindo. Jakarta.

Lasley, J.F. 1978. Genetics of Livestock Improvement. Prentice Hall, Inc. Englewood Cliffs, New Jersey.

Mustafa, M.I.M., K. Bashir, A. Yousaf, and B. Ahmad. 2002. Repeatability Estimates of Some Productive and Reproductive Traits in 
Red Sindhi Cattle. University of Agriculture Faisalabad, Pakistan.

Pirchner, F. 1968. Population Genetics in Animal Breeding. W.H. Freeman and Company, San Fransisco.

Pollack, J. 1998. Heritability. Cornell University, New York, United States.
Soetarno. 2000. Ilmu Produksi Ternak Perah (ed.II). Fakultas Peternakan Universitas Gadjah Mada, Yogyakarta.

Warwick, E.J.J., M. Astuti, dan W. Hardjosubroto. 1990. Pemuliaan Ternak. Fakultas Peternakan, Universitas Gadjah Mada, Yogyakarta. 